\title{
Crystallographic and chemical composition of otoconia in the salamander Pleurodeles walt
}

\author{
Mustafa Oukda a, Michel François ${ }^{b}$, Hervé Membre ${ }^{a}$, Alain Bautz ${ }^{a}$, \\ Christian Dournon ${ }^{\mathrm{a}, *}$ \\ a UPRES EA 2401: Genetic and Cellular Interactions in Reproduction, Laboratory of Experimental Biology-Immunology, Henri Poincaré University, \\ Nancy-1, P.O. Box 239, 54506 Vandoeuvre-lès-Nancy Cedex, France \\ b UMR 7555 Laboratory of Chemistry of Mineral Solids, Henri Poincaré University, Nancy-1, P.O. Box 239, \\ 54506 Vandoeuvre-lès-Nancy Cedex, France
}

Received 11 August 1998; received in revised form 14 January 1999; accepted 6 February 1999

\begin{abstract}
The aim of the present study was to define the morphology and the crystallographic and chemical composition of otoconia in different regions of the inner ear in Pleurodeles walt (urodele amphibian). The inner ear of adults was microdissected and otoconia were analyzed by scanning electron microscopy (SEM), X-ray diffraction, energy dispersive X-ray (EDX) and transmission electron microscopy. Two types of crystals were detected by SEM. Otoconia had different shapes depending on their location in the membranous labyrinth. One type had a cylindrical body with a triplanar smooth facet at each end, the other ones had either a prismatic shape with flat sides and end faces or a fusiform shape with rounded body and pointed end. The forms corresponded to those previously identified by other authors. These two types of otoconia had different X-ray diffraction patterns. The cylindrical otoconia were calcitic and located in the utricle, the other ones were aragonitic and located in the saccule, lagena and endolymphatic sac. An analysis by EDX indicated that both types of otoconia contained about $95 \%$ calcium with trace quantities of sodium, magnesium, phosphorus, sulfur, chlorine and potassium. Trace amounts of strontium was only found in the aragonitic otoconia. (C) 1999 Elsevier Science B.V. All rights reserved.
\end{abstract}

Key words: Aragonite; Calcite; Inner ear; Equilibration; Amphibian

\section{Introduction}

The utricular, saccular and lagenar maculae are three gravity-sensing regions of the inner ear in poikilothermal vertebrates, i.e. vertebrates without a thermoregulating system. These macular end organs consist of a sensory neuroepithelium overlaid by a mass of otoconia or/and by a single otolith. They provide essential information for orientation and equilibrium, detecting linear accelerations and gravity stimuli. Breschet (1836) defined otoconia as small crystallites (also called 'ear dust') located on the macular regions of vestibular labyrinth, as found in amphibians, sauropsidae and mam-

\footnotetext{
* Corresponding author. Tel.: +33 3839123 15;

Fax: +33 3839124 46; E-mail: christian.dournon@scbiol.u-nancy.fr
}

mals, whereas otoliths (also called 'ear stones') are larger single crystals, as found in some fishes.

In poikilothermal vertebrates, the nature, shape and size of the inner ear crystals, the otoconia, vary from one species to another. The crystals are mosaic biominerals composed of an inorganic phase (mineral) and an organic phase (protein) (Degens et al., 1969; Pote and Ross, 1991; Gauldie, 1993; Fermin et al., 1995). In most of the poikilothermal vertebrates, the mineral phase is calcium carbonate in the form of vaterite, aragonite and/or calcite depending on the species. Only cyclostomes, primitive vertebrates, have otoconia or otoliths with calcium phosphate in the crystal form of apatite (Carlström, 1963). All the gnathostomes have calcium carbonate crystals but in different crystallographic forms.

In fishes, the crystallographic structures of the static 
bodies in the different regions of the inner ear are very similar. In chondrichthyes, the otoconia are composed of pure aragonite, except in the dog fish Squalus acanthias which possesses calcitic crystals (Carlström, 1963; Vilstrup, 1951). In osteichthyes, the situation is complex. The holostei present a coexistence of crystals of two crystallographic forms, vaterite otoconia and aragonite otolith. In the chondrostei, Acipenser possesses otoconia and otolith of pure vaterite, whereas Polypterus has both crystal forms as in holostei (Carlström, 1963; Marmo et al., 1992). In the teleostei, otolith consists of aragonite (Carlström, 1963; Degens et al., 1969). In the living coelacanth Latimeria chalumnae, the static body is a polycrystalline otolith of aragonite as in teleostei, whereas in the dipnoans, the lung fish Protopterus dolloi has only otoconia of aragonite (Carlström, 1963).

In amphibians, previous studies on inner ears have dealt mostly with anurans that have supposedly only aragonitic otoconia (Funaoka and Toyota, 1928; Carlström and Engström, 1955; Carlström, 1963; Parson and Cardell, 1965; Lim, 1974; Rosauer and Redmond, 1985). However, the presence of calcitic otoconia in the inner ear of anurans and urodeles was recently reported (Lewis and Pawley, 1981; Pote and Ross, 1993; Wiederhold et al., 1995; Kido and Takahashi, 1997). Moreover, Marmo et al. (1983a) using X-ray diffraction showed in Rana esculenta the presence of calcitic crystals in the utricle and of aragonitic crystals in the saccule, lagena and endolymphatic sac. Concerning the urodeles, the morphology of membranous labyrinth had been studied in 55 species by Lombard (1977). Unfortunately, in Lombard's studies tissues were decalcified and the otoconia were extracted.

In reptiles, in some species of anapsida and lepidosauria, a ratio of $3: 1$ was estimated for aragonitic:calcitic otoconia (Carlström, 1963). In the utricle of the turtle Chrysemys picta belli, otoconia are entirely of the calcite type; in the saccule and lagena, most of the otoconia consist of aragonite and occasional otoconia consist of calcite (Ross and Pote, 1984). In the lizard Podarcis sicla (Marmo et al., 1981) and in the alligator Alligator mississipiensis (Ross and Pote, 1984), the utricle and lagena contain only calcitic otoconia and the saccule contains both aragonitic and some calcitic otoconia. In Podarcis, the endolymphatic sac contains only aragonitic otoconia (Marmo et al., 1981). In birds and mammals, all the otoconia consist of crystalline calcium carbonate in the form of calcite (Carlström et al., 1953; Ross and Peacor, 1975; Ballarino et al., 1985).

At the present time, the X-ray diffraction and the energy dispersive X-ray methods appear to be the most powerful and accurate tools to identify the nature and structure of the otoconia. This study reports on the crystallographic and chemical composition of otoconia in the salamander Pleurodeles waltl. It is a part of a large program concerning the ontogenesis of the inner ear during the development of Pleurodeles in ground conditions and in space flight conditions.

\section{Materials and methods}

\subsection{Animals}

The Pleurodeles waltl (urodele amphibian) used in this study were chosen from the standard strain reared in our laboratory. Thirty-six 1-3-year-old animals whose mean body weight was $40 \pm 10 \mathrm{~g}$ and mean length $13 \pm 4 \mathrm{~cm}$ were used. The youngest animals (1year-old) were regarded as adults because differentiation of the inner ear was achieved. The animals were treated in accordance with the principles of the Declaration of Helsinki.

\subsection{Preparation of the samples for light microscopy}

Animals were anesthetized with $0.1 \%$ ethyl $p$-aminobenzoate (Benzocaine, Sigma Chemical Co., St. Louis, MO, USA) and under general anesthesia, they were decapitated. To access the otic capsules from the roof of the mouth, the lower jaws were removed and the head muscles surrounding the otic capsules were cut away. Then the remaining pieces were fixed in $1.25 \%$ glutaraldehyde in $0.1 \mathrm{M} \mathrm{pH} 7.4$ sodium cacodylate buffer solution during $12 \mathrm{~h}$ at $4^{\circ} \mathrm{C}$. The osmolarity of this solution was $260 \mathrm{mOs} / \mathrm{kg}$, similar to that found in the blood. The osmolarity was verified with a Knauer type ML semi-microosmometer (Dr. H. Knauer Wissenschaftl. Geräte $\mathrm{GmbH}$ and Co. KG, Bad Homburg, Germany). After fixation, the pieces were washed during $2 \mathrm{~h}$ at $4^{\circ} \mathrm{C}$ in $0.125 \mathrm{M}, \mathrm{pH} 7.4$ sodium cacodylate buffer solution, the osmolarity of which was adjusted to $260 \mathrm{mOs} / \mathrm{kg}$ with $0.01 \mathrm{M}$ sucrose. The pieces were dehydrated with increasing concentrations of ethanol (30\% to $100 \%, 15 \mathrm{~min}$ each), then treated with propylene oxide $(3 \times 30 \mathrm{~min})$, infiltrated by 812 epoxy resin and placed in an oven for 3 days at $60^{\circ} \mathrm{C}$. Two $3-\mu \mathrm{m}$ transverse sections were cut with a Reichert Ultracut ultramicrotome (Reichert-Jung GmbH, Heidelberg, Germany) equipped with glass knives. The histological sections were stained with $1 \%$ toluidine blue and $1 \%$ sodium borate solutions and were observed with a Leitz Orthoplan light microscope.

\subsection{Dissecting otoconia for scanning electron microscopy (SEM)}

The inner ear was dissected from the roof of the 

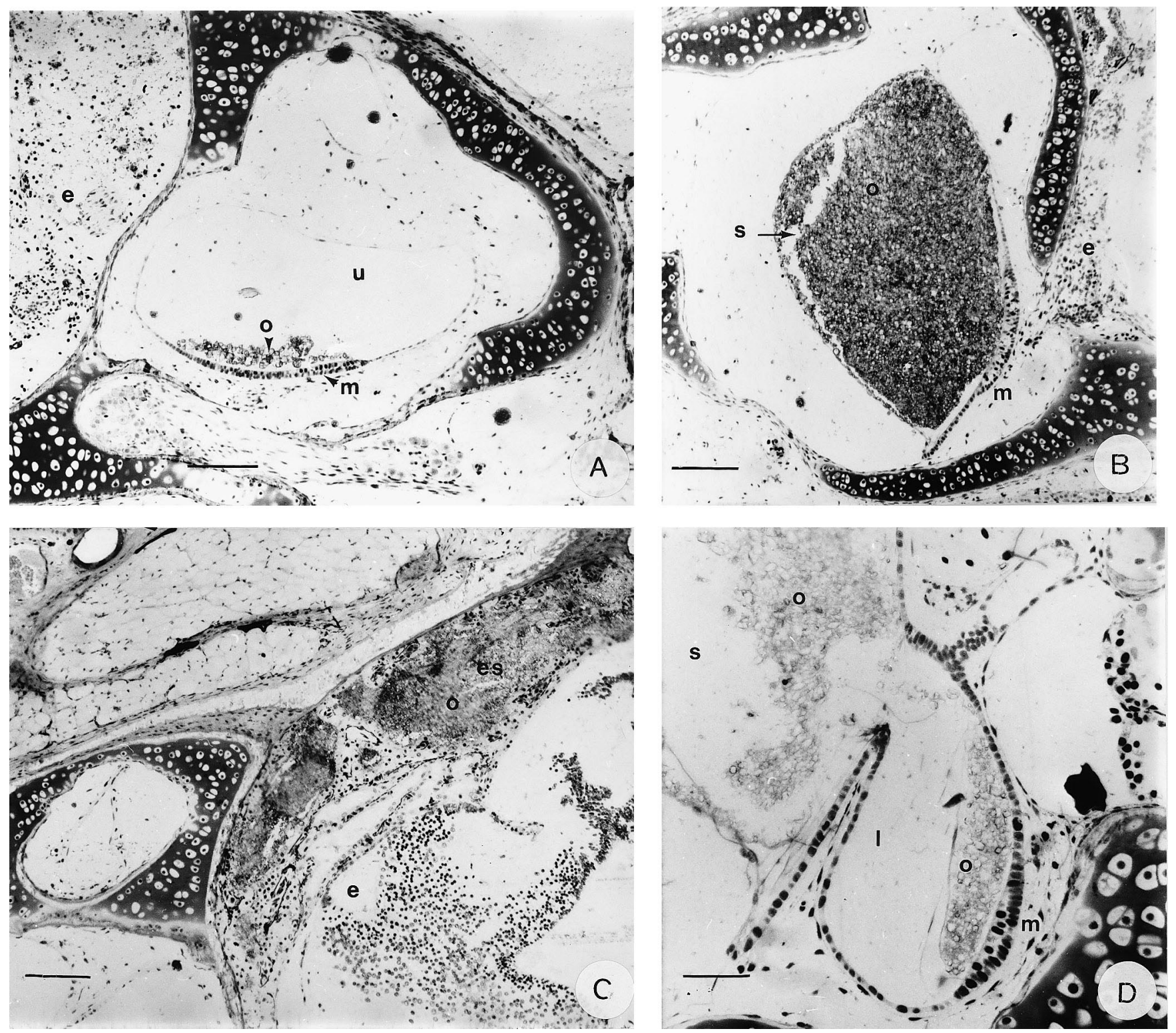

Fig. 1. Histological transverse sections (e: encephalic region; es: endolymphatic sac; 1: lagena; m: macula; o: otoconia; s: saccule; u: utricle). A: Utricle and utricular otoconia on the macula. Magnification $\times 12.8$. Bar $=100 \mu \mathrm{m}$. B: Saccule and saccular otoconia and macula. Magnification $\times 12.8$. Bar $=100 \mu \mathrm{m}$. C: Endolymphatic sac and otoconia. Magnification $\times 12.8$. Bar $=100 \mu \mathrm{m}$. D: Lagena and lagenar otoconia and macula. Magnification $\times 32$. Bar $=250 \mu \mathrm{m}$.

mouth on freshly killed animals. The position of the utricle could be identified by the convergence region of the semicircular canals. The saccule, which appeared lens-shaped, was ventro-laterally positioned by comparison with the utricle. The lagena appeared as an evagination of the posterior part of the saccule. When the cartilage which protected the inner ear was removed with fine forceps, the otoconia from these three regions were gently picked up with a Lindemann micropipette, then placed on glass slides. To eliminate the risk of contamination, the otoconia of these different regions were taken from three different inner ears. To access the flattened endolymphatic sac which is connected to the saccule by a narrow duct of $40 \mu \mathrm{m}$ internal diameter, saccule, utricle and lagena were eliminated and the floor of the brain was cut with a microscalpel. The otoconia were picked up using the method described above. Several samples were used for each region, and the same observations were always made.

The otoconia samples were rinsed with sterile distilled water using micropipettes, dried at ambient temperature, and dehydrated by hexamethyldisilazane (Sigma) without using the critical-point method. The otoconia were coated with a 20-30-nm gold layer, then examined with a Cambridge Stereoscan 240 scanning electron microscope (Leica-Cambridge Ltd, Cambridge, UK). The 
size of the crystals was directly measured through SEM micrographs.

\subsection{X-ray diffraction}

Otoconia were removed using the above method, glued with adhesive tape on a copper grid and examined by transmission with a Nonius Guinier camera $(R=57.3 \mathrm{~mm}, U=40 \mathrm{kV}, I=20 \mathrm{~mA})$ using monochromatized ( $\alpha$ quartz monochromator) $\mathrm{Co}-\mathrm{K} \alpha_{1}$ radiation. This method is particularly appropriate for small samples. The diffraction patterns were recorded on films, visually examined and read by an LS20 optical densitometer (Malmros and Werner, 1973; Johansson et al., 1980). Identifications of the phases were made using the DIFFRAC-AT (Nusinovici and Winter, 1994) program including the ICDD Powder Diffraction Data Base, ASTM files 24-0027 and 41-1475 were used to identify calcite and aragonite respectively.

\subsection{Energy dispersive $X$-ray analysis (EDX)}

A quantitative elemental microanalysis was conducted to determine the composition of the inorganic phase of otoconia. Otoconia from all the regions of the labyrinth were removed with similar techniques as used for SEM, embedded in epon and prepared for transmission electronic microscopy (TEM) without using any solvent. Ultrathin sections $(100 \mathrm{~nm})$ were cut using a Reichert Ultracut ultramicrotome (Reichert-Jung $\mathrm{GmbH}$, Heidelberg, Germany) equipped with diamond knives and mounted on 150-mesh nickel grids. The otoconia were analyzed using a Philips CM20 transmission electronic microscope operating at $200 \mathrm{kV}$. Element analyses were performed by EDX using a EDAX, DX 4 spectrometer. The diameter of the electron beam was about $10 \mathrm{~nm}$. The elemental histograms were evaluated with regard to the $\mathrm{K} \mu$ line, whereas $\mathrm{X}$-ray spectra were collected in the range $0-20 \mathrm{keV}$ for $60 \mathrm{~s}$.

\section{Results}

\subsection{Morphological aspects of the otoconia}

The utricular macula had an anatomical position located in the horizontal plan (Fig. 1A) while the saccular macula was nearly vertical (Fig. 1B). The quantity of otoconia differed according to the regions. In the utricle (Fig. 1A) and lagena (Fig. 1D), the quantity was clearly smaller than that in the saccule or in the endolymphatic sac (Fig. 1B,C).

Morphological differences between the otoconia of the utricle on the one hand and the otoconia of the saccule, lagena and endolymphatic sac on the other
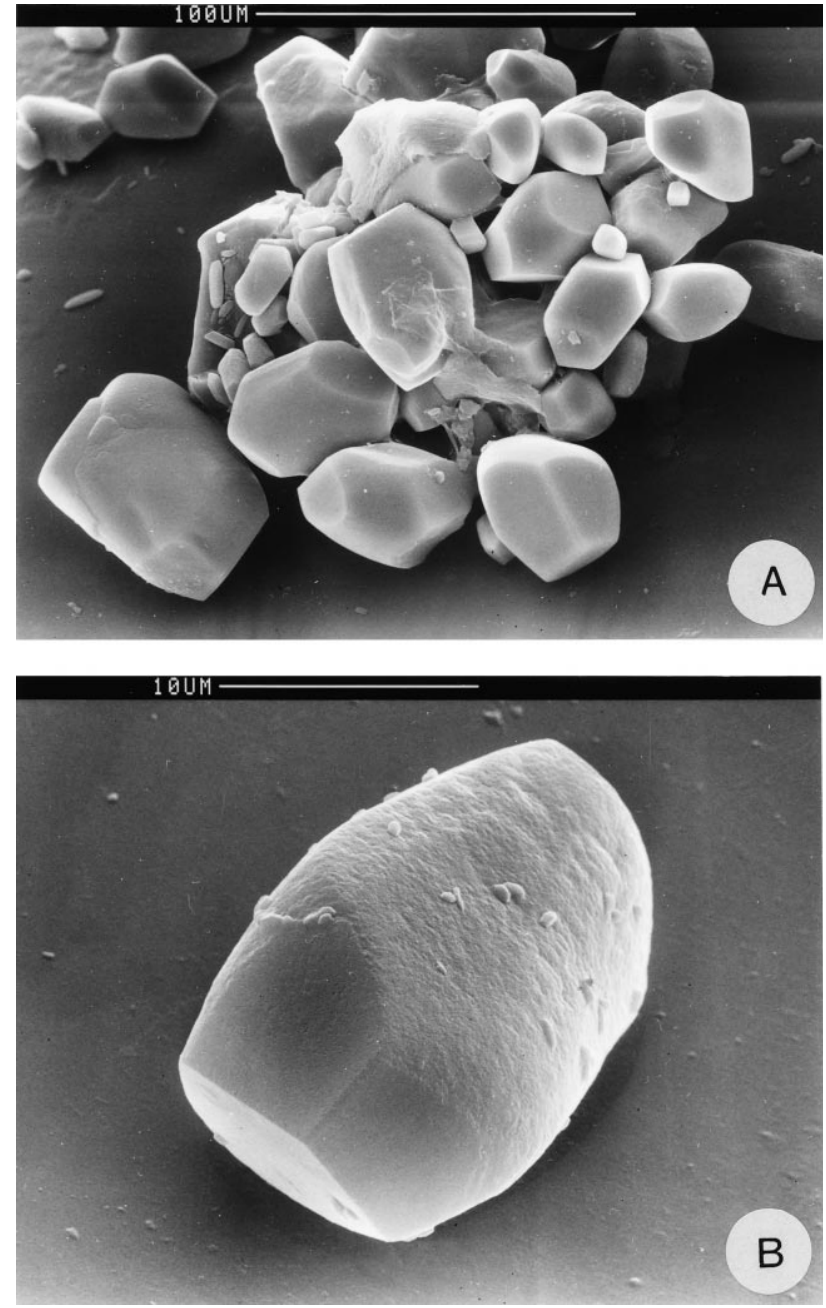

Fig. 2. Calcitic otoconia from the utricle. A: Calcitic crystals of rhombohedral type with rough barrel-shaped body ended by three characteristic planar facets with smooth surface. From 2 to $52 \mu \mathrm{m}$ in length and 10 to $47 \mu \mathrm{m}$ in width. B: Detail.

hand were revealed by SEM measurements (Table 1). In the utricle, the otoconia corresponded to a calcitic morphology of rhombohedral type. They had a barrelshaped body ended by three characteristic planar facets with a smooth surface. These otoconia were $2-52 \mu \mathrm{m}$ in length and $10-47 \mu \mathrm{m}$ in width (Fig. 2A,B). In the saccule, lagena and endolymphatic sac, the otoconia corresponded to polymorphic aragonite of orthorhombic type. These otoconia had a long prismatic pseudohexagonal (slab-shaped) body with flat sides ended by oblique sheared faces (Fig. 3A), or a fusiform (rugbyball-shaped) body with pyramidal pointed ends, also called pinacoid by Pote and Ross (1991) (Fig. 3B). Aragonitic or calcitic crossing crystals were seldom observed (Fig. 3C,D).

The distribution of these two types of crystals had different ratios and dimensions according to the regions of the membranous labyrinth. In the saccule, the pris- 

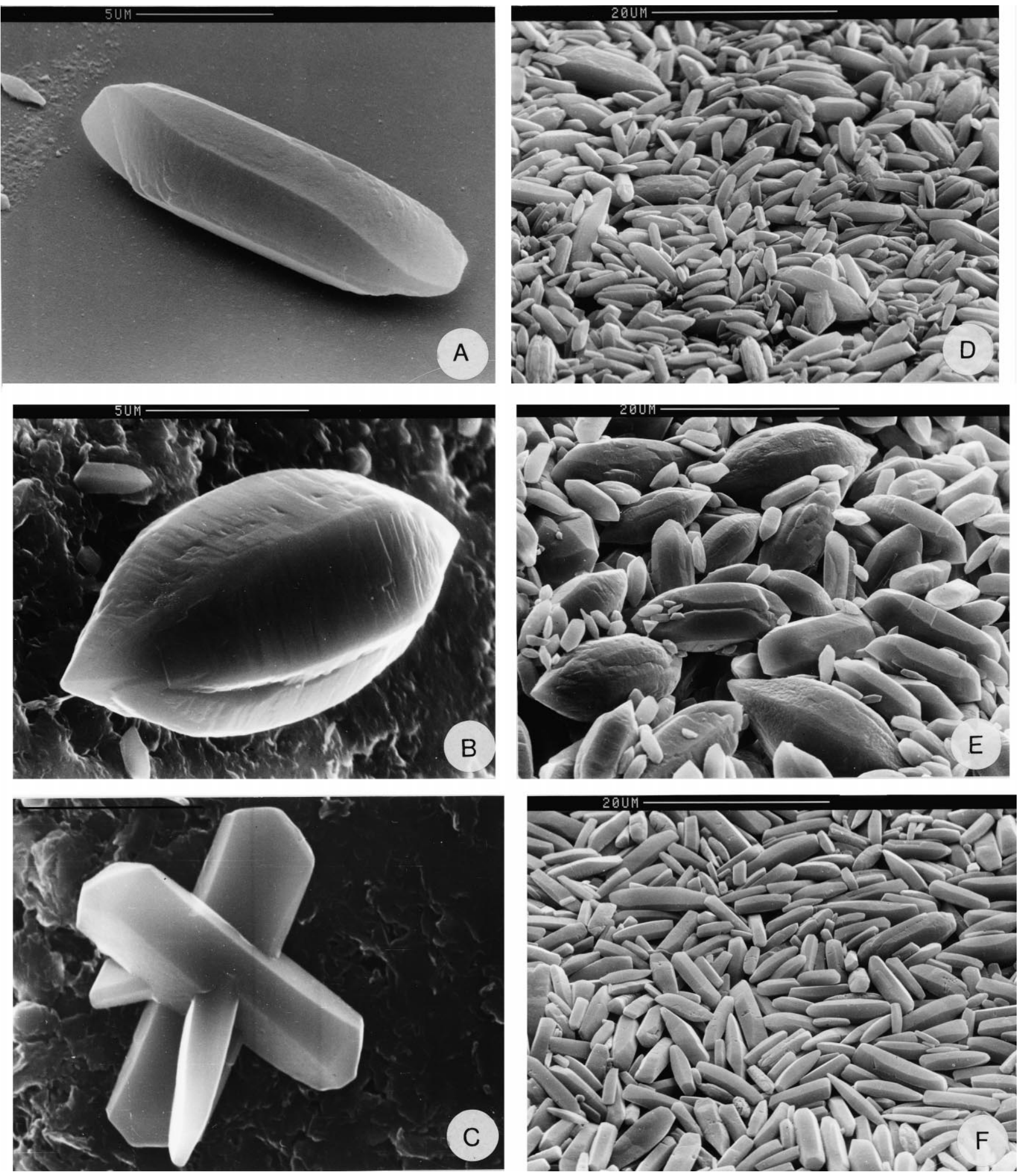

Fig. 3. Aragonitic otoconia. A: Prismatic aragonitic otoconium characterized by a long pseudohexagonal body with flat sides ended by oblique sheared faces. B: Fusiform aragonitic otoconium characterized a rugby-ball-shaped body with pyramidal pointed ends, also called pinacoid otoconium by Pote and Ross (1991). C: Crossing crystal of aragonite originating from the saccule. Bar $=4 \mu \mathrm{m}$. D: Saccular otoconia. Prismatic otoconia: more numerous; length varying from 1 to $22 \mu \mathrm{m}$. Fusiform otoconia less numerous; length from 2 to $40 \mu \mathrm{m}$. E: Lagenar otoconia. Prismatic otoconia; length from 1 to $20 \mu \mathrm{m}$. Fusiform otoconia; length from 2 to $30 \mu \mathrm{m}$. F: Otoconia from endolymphatic sac. Prismatic otoconia only detected; length from 1 to $30 \mu \mathrm{m}$. Fusiform otoconia not found. 


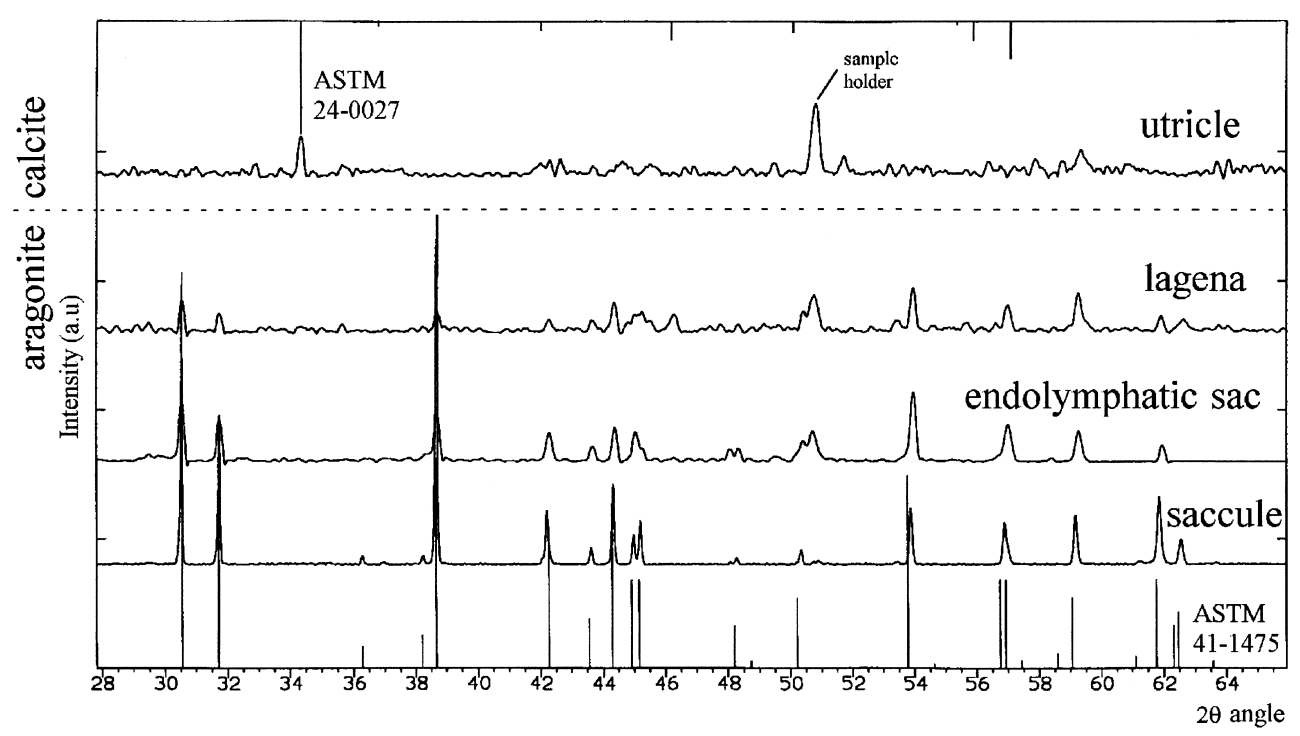

Fig. 4. X-ray diffraction analysis. The spectra are presented according to the different regions of the membranous labyrinth. Up: spectrum of calcite. Down: three spectra of aragonite and the reference.

matic otoconia (aragonitic) were the most common with a size varying from 1 to $22 \mu \mathrm{m}$ in length; sometimes a very long crystal up to $125 \mu \mathrm{m}$ could be observed. Fusiform otoconia (aragonitic) were less numerous than prismatic otoconia and were $2-40 \mu \mathrm{m}$ in length (Fig. 3D). In the lagena the two types of otoconia were distributed in the same proportion; the prismatic crystals were 1-20 $\mu \mathrm{m}$ in length, whereas the fusiform crystals were $2-30 \mu \mathrm{m}$ (Fig. 3E). In the endolymphatic sac, only prismatic otoconia were observed, ranging from 1 to $30 \mu \mathrm{m}$ in length; fusiform otoconia were not found (Fig. 3F).

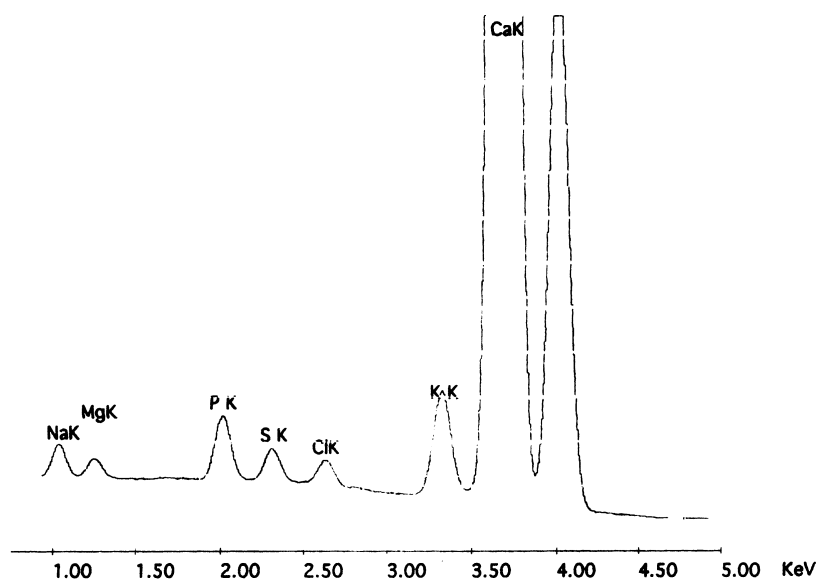

Fig. 5. Energy dispersive X-ray spectrum of a calcitic otoconium from a Pleurodeles waltl adult. The highest $\mathrm{Ca} \mathrm{K}-\alpha$ peak and the smaller Ca K- $\beta$ peak were clearly obtained. Other smaller $\mathrm{K}$ peaks corresponding to atomic elements $\mathrm{Na}, \mathrm{Mg}, \mathrm{P}, \mathrm{S}, \mathrm{Cl}$ and $\mathrm{K}$ were detected.

\subsection{Crystallographic structure}

In adults of Pleurodeles waltl, the X-ray diffraction patterns of otoconia confirmed that the otoconia located in the utricle were in the crystal form of calcite (in reference with the data base ASTM 24-0027), while the prismatic or the fusiform otoconia located in the saccule, lagena and endolymphatic sac were in the crystal form of aragonite (in reference with the data base ASTM 41-1475) (Fig. 4).

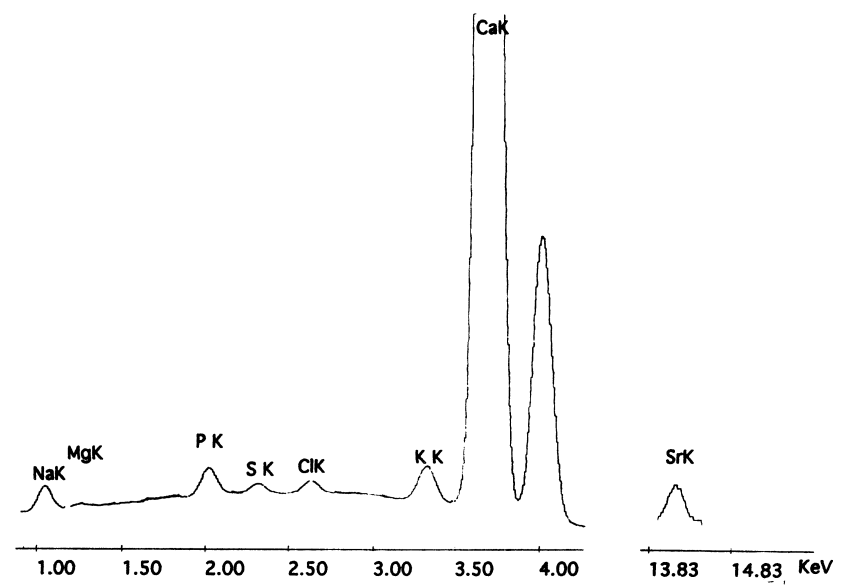

Fig. 6. Energy dispersive X-ray spectrum of an aragonitic otoconium from a Pleurodeles waltl adult. The highest $\mathrm{Ca} \mathrm{K}-\alpha$ peak and the smaller $\mathrm{Ca}$ K- $\beta$ peak were here also clearly obtained. Other smaller $\mathrm{K}$ peaks corresponding to atomic elements $\mathrm{Na}, \mathrm{Mg}, \mathrm{P}, \mathrm{S}$, $\mathrm{Cl}, \mathrm{K}$ and $\mathrm{Sr}$ were detected. 
Table 1

Distribution and size of crystal types in different regions of the membranous labyrinth

\begin{tabular}{llll}
\hline Region & Crystal type & Length $($ in $\mu \mathrm{m})$ & Relative ratio \\
\hline Utricle & rhombohedric & $2-52$ & $100 \%$ rhombohedric \\
Saccule & prismatic & $1-22$ & prismatic $\gg$ fusiform \\
& fusiform & $2-40$ & prismatic $\simeq$ fusiform \\
Lagena & prismatic & $1-20$ & $100 \%$ prismatic \\
& fusiform & $2-30$ & $1-30$ \\
\hline
\end{tabular}

\subsection{Chemical analysis by EXD}

Quantitative microchemical analysis of thin sections of calcitic and aragonitic otoconia of adults of Pleurodeles waltl by EDX is presented in Table 2 and Figs. 5 and 6 . The elemental composition of the two types of otoconia was primarily characterized by a high weight percentage and an high atomic percentage of calcium concentration (Table 2). In the X-ray spectra, two distinct peaks of calcium ( $\mathrm{Ca} \mathrm{K}-\alpha$ and $\mathrm{Ca} \mathrm{K}-\beta)$ were identified and lower peaks of sodium, magnesium, phosphorus, sulfur, chlorine and potassium were present in trace quantities. Strontium was only detected in the aragonitic otoconia (Fig. 6). The composition in $\mathrm{Ca}, \mathrm{Cl}$, and $\mathrm{K}$ was very similar in the calcitic and aragonitic otoconia. In the calcitic otoconia, the quantity of $\mathrm{Na}$ was lower than in the aragonitic otoconia, while the quantity of $\mathrm{Mg}, \mathrm{P}$, and $\mathrm{S}$ was higher (Table 2 ).

\section{Discussion}

The sole morphology of the otoconia cannot be taken as a proof of identity of the crystallographic forms as calcite or aragonite, and crystallographic methods such as X-ray diffraction must be used to determine exactly the crystalline constitution. Carlström (1963) investigated by X-ray diffraction the crystallographic structure of the otoconia from three species of urodeles and three species of anurans among 58 species of vertebrates, and reported only the presence of pure aragonite in the studied amphibians. These results were not in agreement with those obtained with the frog Rana esculenta in which both aragonitic and calcitic otoconia were detected by morphological and X-ray diffraction analyses (Marmo et al., 1983b). More recently, in different species of anurans and urodeles, the morphological features of otoconia removed from different sites of the adult inner ear were examined using scanning electron microscope (Pote and Ross, 1993; Wiederhold et al., 1995; Kido and Takahashi, 1997). All the utricular otoconia presented a calcitic morphology which resembled calcitic otoconia removed from the labyrinth of reptiles, birds or mammals (Ross and Peacor, 1975; Marmo et al., 1981; Ballarino et al., 1985). Our results obtained by X-ray diffraction clearly demonstrate the presence of calcitic otoconia in the utricle and of aragonitic otoconia in the saccule, lagena and endolymphatic sac in Pleurodeles waltl. As reported in Section 1, in fishes, with the exception of previous results suggesting that the otoconia of sharks were calcitic (Vilstrup, 1951), all the otoconia have a vaterite or/and aragonite form whereas in birds and mammals all the otoconia have a calcitic form. This study shows that amphibians and reptiles possess both forms, aragonitic and calcitic. Pending confirmation of the result in the sharks with

Table 2

Chemical composition of calcitic and aragonitic otoconia of Pleurodeles waltl adults

\begin{tabular}{lccccc}
\hline $\begin{array}{l}\text { Elements } \\
\text { K } \alpha \text { line })\end{array}$ & \multicolumn{2}{l}{ Weight $\%$} & & \multicolumn{2}{c}{ Atomic $\%$} \\
\cline { 2 - 3 } \cline { 5 - 6 } & Calcitic otoconia & Aragonitic otoconia & & Calcitic otoconia & Aragonitic otoconia \\
\hline $\mathrm{Na}$ & $0.555 \pm 0.022$ & $0.729 \pm 0.043$ & & $0.951 \pm 0.041$ & $1.264 \pm 0.073$ \\
$\mathrm{Mg}$ & $0.292 \pm 0.020$ & $0.106 \pm 0.006$ & & $0.472 \pm 0.032$ & $0.173 \pm 0.006$ \\
$\mathrm{P}$ & $1.132 \pm 0.047$ & $0.728 \pm 0.216$ & & $1.449 \pm 0.058$ & $0.939 \pm 0.279$ \\
$\mathrm{~S}$ & $0.520 \pm 0.060$ & $0.293 \pm 0.048$ & & $0.485 \pm 0.158$ & $0.365 \pm 0.059$ \\
$\mathrm{Cl}$ & $0.354 \pm 0.086$ & $0.338 \pm 0.093$ & & $0.389 \pm 0.101$ & $0.371 \pm 0.102$ \\
$\mathrm{~K}$ & $1.836 \pm 0.354$ & $1.974 \pm 0.325$ & & $1.864 \pm 0.357$ & $2.016 \pm 0.334$ \\
$\mathrm{Ca}$ & $95.311 \pm 0.449$ & $94.956 \pm 0.227$ & & $94.390 \pm 0.458$ & $94.471 \pm 0.181$ \\
$\mathrm{Sr}$ & 0 & $0.880 \pm 0.205$ & & 0 & $0.401 \pm 0.092$ \\
\hline
\end{tabular}

Weight \%: percentage of weight of the measured element in comparison with all the measured elements with the exception of carbon and oxygen. Atomic \%: percentage of atoms of the measured element in comparison with all the measured elements with the exception of carbon and oxygen. 
a new X-ray diffraction analysis and excluding the fossil fishes because of a potential crystallographic transformation of the calcium carbonate as a function of time, we also propose the hypothesis that production of calcitic crystals appeared first in the utricle of amphibians. The amphibians are vertebrates which have conquered the terrestrial environment. The life change from the aquatic to the terrestrial territory could be linked to a replacement of aragonitic otoconia by calcitic otoconia in the utricle, i.e. to a modification of the genetic control of the biomineral syntheses during phylogenetic processes. We are currently testing this hypothesis by studying the inner ear organogenesis in the urodele Pleurodeles waltl.

In all amphibian species examined including Pleurodeles, the mature calcitic otoconia located in the utricle have nearly the same size $(50 \mu \mathrm{m} \pm 3)$ and the same morphology (Pote and Ross, 1993; Steyger et al., 1995; Kido and Takahashi, 1997), but the size and distribution of the aragonitic polymorphic otoconia (prismatic and fusiform) located in the saccule and lagena vary from one species to another. The otoconia located in the endolymphatic sac present predominantly a prismatic shape and have different sizes (Pote and Ross, 1993; Steyger et al., 1995; Kido and Takahashi, 1997). The formation, biomineralization and the size of otoconia are related to the otoconial organic matrix consisting of a core and peripheral proteins (Salamat et al., 1980; Lowenstam, 1981; Campos et al., 1984; Pote and Ross, 1986; Fermin, 1993; Hallworth et al., 1995; Steyger and Wiederhold, 1995). Phosphate and sulfate groups could be involved in the otoconia biomineralization process and could therefore influence the mineral density of the otoconia (Crespo et al., 1993; Takumida and Zhang, 1997).

For Anniko et al. (1987), the incorporation of calcium into otoconia would result from a calcic flow initiated by macular epithelial cells and would not be due to a general supersaturating of calcium into the endolymphatic fluid. In Pleurodeles, the composition in calcium, chlorine, and potassium was nearly similar in the calcitic and aragonitic otoconia, and in mice, no significant differences were shown in calcium and potassium between saccular and utricular otoconia (Lopez-Escamez et al., 1992; Campos et al., 1992). There are traces of some elements in Pleurodeles waltl otoconia, such as sodium, magnesium, phosphorus, chlorine, potassium, and strontium. Lychakov and Lavrova (1994) suggested that sodium is bound to proteins of the organic matrix and plays a role in the otolith and otoconia growth while magnesium inhibits the crystalline growth from calcium salts. In the calcitic utricular and saccular otoconia of the guinea pig, Takumida and Zhang (1997) found the same traces of these elements as in calcitic otoconia of Pleurodeles waltl. To our knowledge, our results demonstrate, for the first time, strontium incorporation in otoconia in a non-marine species. Strontium is known to favor the formation of aragonite from calcium carbonate (Carlström, 1963). In the absence of strontium, embryos of Aplysia californica have no static body (Bidwell et al., 1986), normally constituted of aragonite (Wiederhold et al., 1986).

In conclusion, in the utricle of Pleurodeles waltl, the otoconia have the crystallographic form of calcite while in the other regions of the membranous labyrinth, the otoconia have the crystallographic form of aragonite with its polymorphic aspect. A clear difference between the chemical composition of the calcitic and aragonite otoconia is the presence of strontium which was only detected and measured in aragonite otoconia.

\section{Acknowledgements}

We thank Christiane Tankosic for her help in looking after the animals, Jacqueline Chanel, Monique Simonetti and Luc Marchal from the Service général de Microscopie électronique and Jaafar Ghanbaja from the Service général de Microanalyses X of the Henri Poincaré University for their technical assistance. This work was supported by the French space agency, the Centre National d'Etudes Spatiales (CNES) (Grant 5916/Cnes/ 98) and by the Ministère de l'Education Nationale, de la Recherche et de la Technologie.

\section{References}

Anniko, M., Wikström, S.O., Wroblewski, R., 1987. X-ray microanalytic studies on developing otoconia. Acta Otolaryngol. (Stockh.) 104, 285-289.

Ballarino, J., Howland, H.C., Skinner, H.C.W., Brothers, E.W., Bassett, W., 1985. Studies of otoconia in the developing chick by polarized light microscopy. Am. J. Anat. 174, 131-144.

Bidwell, P.J., Paige, J.A., Kuzirian, A.M., 1986. Effect of strontium on the embryonic development of Aplysia californica. Biol. Bull. 170, 75-90.

Breschet, G., 1836. Recherches anatomiques et physiologiques sur l'organe de l'ouie et sur l'audition dans l'homme et les animaux vertébrés. Mém. Acad. Méd, Paris 5, 229-523.

Campos, A., Ciges, M., Crespo, P.V., 1984. Mineralization in the newborn rat statoconia. An EDAX study. Acta Otolaryngol. (Stockh.) 97, 475-478.

Campos, A., Lopez-Escamez, J.A., Canizares, F.J., Crespo, P.V., 1992. Electron probe X-ray microanalysis of $\mathrm{Ca}$ and $\mathrm{K}$ distributions in the otolithic membrane. Micron Microsc. Acta 23, 349350.

Carlström, D.A., 1963. A crystallographic study of vertebrate otoliths. Biol. Bull. 125, 441-463.

Carlström, D.A., Engström, A., 1955. The ultrastructure of otoconia. Acta Otolaryngol. (Stockh.) 45, 14-18.

Carlström, D.A., Engström, A., Hjorth, S., 1953. Electron microscopic and X-ray diffraction studies of statoconia. Laryngoscope $63,1052-1057$. 
Crespo, P.V., Lopez-Escamez, J.A., Canizares, F.J., Campos, A., 1993. X-ray microanalytical determination of $\mathrm{P}, \mathrm{S}$ and $\mathrm{K}$ concentration in the gelatinous membrane of the utricle. Acta Otolaryngol. (Stockh.) 113, 176-180.

Degens, E.T., Deuser, W.G., Haedrich, R.L., 1969. Molecular structure and composition of fish otoliths. Mar. Biol. 2, 105-113.

Fermin, C.D., 1993. High resolution and image processing of otoconia matrix. Microsc. Res. Tech. 25, 297-303.

Fermin, C.D., Martin, D.S., Li, Y.T., Li, S.C., 1995. The glycan ketatan sulfate in inner ear crystals. Cell. Mol. Biol. 41, 577-591.

Funaoka, S., Toyota, S., 1928. Untersuchungen über die transmikroskopische Structur des Lebewesenkörpers. III. Über die chemische Natur und die Entstehung der Otolithen der Rana esculenta. Folia Anat. Jap. 6, 323-325.

Gauldie, R.W., 1993. Continuous and discontinuous growth in the otolith of Macruronus novaezelandiae (Merlucciidae: Teleostei). J. Morphol. 216, 271-294.

Hallworth, R., Wiederhold, M.L., Campbell, J.B., Steyger, P.S., 1995. Atomic force observation of otoconia in the newt. Hear. Res. 85, $115-121$

Johansson, K.E., Palm, T., Werner, P.E., 1980. An automatic microdensitometer for X-ray powder diffraction photographs. J. Phys. E Sci. Instrum. 13, 1289-1291.

Kido, T., Takahashi, M., 1997. Scanning electron microscopic of amphibians otoconia. Auris Nasus Larynx 24, 125-130.

Lewis, E.R., Pawley, J.B., 1981. Direct SEM study of frozen inner ear. Scanning 4, 131-140.

Lim, D.J., 1974. The statoconia of the non-mammalian species. Brain Behav. Evol. 10, 37-41.

Lombard, R.E., 1977. Comparative morphology of the inner ear in salamanders. In: Hecht, M.K., Szalay, F.S. (Eds.), Contribution to Vertebrate Evolution, New York, Vol. 2, pp. 1-140.

Lopez-Escamez, J.A., Crespo, P.V., Canizares, F.J., Campos, A., 1992. Dependence between saccule and utricle in $\mathrm{Ca}^{2+}$ and $\mathrm{K}^{+}$ concentrations determined by electron probe X-ray microanalysis. Micron Microsc. Acta 23, 367-368.

Lowenstam, H.A., 1981. Minerals formed by organisms. Science 211, 1126-1131.

Lychakov, D.V., Lavrova, E.A., 1994. The content of electrolytes $(\mathrm{Na}, \mathrm{K}, \mathrm{Ca}, \mathrm{Mg})$ in vertebrate otoliths and otoconia. Zh. Evol. Biokhim. Fiziol. 30, 99-105.

Malmros, G., Werner, P.E., 1973. Automatic densitometer measurements of powder diffraction photographs. Acta Chem. Scand. 27, 483.

Marmo, F., Franco, E., Balsamo, G., 1981. Scanning electron microscopic and X-ray diffraction studies of otoconia in the lizard Podarcis s. sicula. Cell Tissue Res. 218, 265-270.

Marmo, F., Balsamo, G., Franco, E., 1983a. The formation of oto- liths in the frog Rana esculenta. Scanning electron microscopic and X-ray diffraction studies. Acta Zool. 67, 533-561.

Marmo, F., Balsamo, G., Franco, E., 1983b. Calcite in the statoconia of amphibians: A detailed analysis in the frog Rana esculenta. Cell Tissue Res. 233, 35-43.

Marmo, F., Ariani, A.P., Balsamo, G., Avallone, B., 1992. Scanning electron microscopy and X-ray diffraction studies of the macular crystals in the Chondrostean fish Erpetoichthys calabaricus (Smith). Acta Zool. 73, 203-206.

Nusinovici, J., Winter, M.J., 1994. Diffrac-AT search: search/match using full trace as imput. Adv. X-ray Anal. 37, 59-66.

Parson, J., Cardell, R.R., 1965. Analysis of statoliths by X-ray diffraction and emission spectroscopy. Trans. Am. Microsc. Soc. 84, 415-421.

Pote, K.G., Ross, M.D., 1986. Ultrastructural morphology and protein content of the internal organic material of the rat otoconia. J. Ultrastruct. Res. 95, 61-70.

Pote, K.G., Ross, M.D., 1991. Each otoconia polymorph has a protein unique to the polymorph. Comp. Bioch. Physiol. 98, 287-295.

Pote, K.G., Ross, M.D., 1993. Utricular otoconia of some amphibians have calcitic morphology. Hear. Res. 67, 189-197.

Rosauer, E.A., Redmond, J.R., 1985. Comparative crystallography of vertebrate otoconia. J. Laryngol. Otol. 99, 21-28.

Ross, M.D., Peacor, D.R., 1975. The nature and crystal growth of otoconia in the rat. Ann. Otol. Rhinol. Laryngol. 84, 22-36.

Ross, M.D., Pote, K.G., 1984. Some properties of otoconia. Phil. Trans. R. Soc. Lond. B 304, 445-452.

Salamat, M.S., Ross, M.D., Peacor, D.R., 1980. Otoconial formation in the fetal rat. Ann. Otol. 89, 229-238.

Steyger, P.S., Wiederhold, M.L., 1995. Visualization of newt aragonite otoconial matrices using transmission electron microscopy. Hear. Res. 92, 184-191.

Steyger, P.S., Wiederhold, M.L., Batten, J., 1995. The morphogenic features of otoconia during larval development of Cynops pyrrhogaster, the Japanese red-bellied newt. Hear. Res. 84, 61-71.

Takumida, M., Zhang, D.M., 1997. Electron probe X-ray microanalysis of otoconia in guinea pig inner ear: a comparison between young and old animals. Acta Otolaryngol. (Stockh.) 117, 529-537.

Vilstrup, T., 1951. On the formation of the otoliths. Ann. Otol. Rhinol. Laryngol. 60, 974-981.

Wiederhold, M.L., Sheridan, C.E., Smith, N.K.R., 1986. Statoconia formation in molluscan statocysts. Scan. Electron Microsc. 2, 781792.

Wiederhold, M.L., Yamashita, M., Larsen, K., Batten, J., Koike, H., Asashima, M., 1995. Development of the otolith organs and semicircular canals in the Japanese red-bellied newt, Cynops pyrrhogaster. Hear. Res. 84, 41-51. 